Review

\title{
Linking atrial fibrillation with non-alcoholic fatty liver disease: potential common therapeutic targets
}

\author{
Ya-Hui Ding ${ }^{1,3}$, Yuan $\mathrm{Ma}^{1,3}$, Lin-Yan Qian ${ }^{1,3}$, Qiang $\mathrm{Xu}^{1,3}$, Li-Hong Wang ${ }^{1,3}$, Dong- \\ Sheng Huang ${ }^{2,3}$ and Hai Zou ${ }^{1,3}$ \\ ${ }^{1}$ Department of Cardiology, Zhejiang Provincial People's Hospital, Hangzhou 310014, China \\ ${ }^{2}$ Department of Hepatobiliary Surgery, Zhejiang Provincial People's Hospital, Hangzhou 310014, China \\ ${ }^{3}$ People's Hospital of Hangzhou Medical College, Hangzhou 310014, Zhejiang Province, China \\ Correspondence to: Qiang Xu, email: xuqiang@zjheart.com \\ Li-Hong Wang, email: wanglh@zjheart.com \\ Dong-Sheng Huang, email: dshuang@zju.edu.cn \\ Hai Zou, email: haire1993@163.com
}

Keywords: non-alcoholic fatty liver disease, atrial fibrillation, adiponectin, insulin resistance, renin angiotensin aldosterone system

Received: May 23, 2017

Accepted: July 13, 2017

Published: July 24, 2017

Copyright: Ding et al. This is an open-access article distributed under the terms of the Creative Commons Attribution License 3.0 (CC BY 3.0), which permits unrestricted use, distribution, and reproduction in any medium, provided the original author and source are credited.

\begin{abstract}
Non-alcoholic fatty liver disease (NAFLD) and atrial fibrillation (AF) are common chronic non-infectious diseases with rising incidences. NAFLD is an independent risk factor for the onset of $A F$, after adjusting potentially related factors. The pathogenesis of these diseases share several mechanisms including reduced adiponectin level, insulin resistance, and renin angiotensin aldosterone system (RAAS) activation, in addition to activation of common disease pathways that promote inflammation, oxidative stress, and fibrosis. Furthermore, statins and RAAS blockers exert therapeutic effects concurrently on NAFLD and AF. The common pathogenesis of NAFLD and AF may serve as a potential therapeutic target in the future.
\end{abstract}

\section{INTRODUCTION}

Non-alcoholic fatty liver disease (NAFLD) is the most common chronic liver disease worldwide with growing incidence [1]. It is defined by hepatic fat accumulation and hepatic steatosis resulting from factors other than excessive alcohol consumption. There are two forms of NALFD: non-alcoholic fatty liver (NAFL) and non-alcoholic steatohepatitis (NASH) [2]. The incidence of NAFLD varies between studies from 6.3 to $33 \%$ (median $20 \%$ ) due to the diversity of study populations and diagnostic tools used in each study [1]. The incidence of NASH is relatively low, ranging between 3 and $5 \%$. About $30-40 \%$ of NAFL cases progress into fatty liver cirrhosis in 10 years, making NAFLD one of the most common cause of cryptogenic cirrhosis [3]. NAFLD is also considered to be part of multi-organ diseases associated with several other diseases including cardiovascular diseases (CVDs), diabetes, chronic kidney disease, and colorectal cancer $[4,5]$.

Atrial fibrillation (AF), a common arrhythmia, is characterized by chaotic atrial activation accompanied by atrial dynamics degradation. AF complications include thromboembolism, heart failure, and a reduced quality of life [6]. In the 2010 Global Burden of Disease Study, the age-adjusted prevalence of $\mathrm{AF}$ worldwide was reported at 5.96 per 1,000 in men and 3.73 per 1,000 in women. The total number of AF cases is estimated at about 33 million [7], with a growing incidence in recent years. After adjusting for age and sex, Miyasaka et al. reported an AF incidence between 3.04 per 1,000 people in 1980 to 3.68 per 1,000 people in 2000 [8], with a relative increase of $12.6 \%$ over 21 years. The growing incidence of AF is associated with several factors including age, male sex, hypertension, valvar heart disease, chronic heart failure, and thyroid disease. 
Recent clinical investigations revealed a significant increasing in AF cases among patients with NAFLD, suggesting that NAFLD is an independent risk factor for AF [9-13]. This article reviews the current literature about the epidemiology and mechanisms of NAFLD and AF, and discusses the relationship between the two conditions with the aim to provide new insights into the treatment of both NAFLD and AF.

\section{NAFLD and AF in epidemiology}

The incidence of AF is significantly higher in patients with NAFLD compared to patients without NAFLD after adjusting for potentially related factors such as age, sex, blood pressure, and blood glucose level.

In a 10-year follow-up study of 400 patients with type-2 diabetes, Targher et al. found that NAFLD was closely related to a growing risk of incidental AF (odds ratio [OR] 4.49, 95\% confidence interval [CI] 1.6-12.9, $p<0.005)$. The adjusted-OR was 6.38 (95\% CI 1.7-24.2, $p=0.005)$ after adjusting for age, sex, hypertension, and electrocardiographic features (left ventricular hypertrophy and PR interval) [12]. Another cross-sectional study from the same group showed a similar result in 702 patients with type-2 diabetes (OR 3.04, 95\% CI 1.54-6.02, $p<0.001)$ [13]. The risk for AF in patients with NAFLD decreased when adjustments were made for age, sex, systolic blood pressure, glycated hemoglobin HbAlc, estimated glomerular filtration rate, total cholesterol, electrocardiographic left ventricular hypertrophy, chronic obstructive pulmonary disease, and prior history of heart failure, valvar heart disease, or hyperthyroidism (adjustedOR 5.88, 95\% CI 2.72-12.7, $p<0.001)$. Furthermore, a 16.3-year study of 958 middle-aged patients with hypertension from the Oulu Project Elucidating Risk of Atherosclerosis (OPERA) cohort revealed that NAFLD was associated with an increased risk of AF (Hazard ratio 1.96, 95\% CI 1.29-2.97) [10]. 14.9\% of patients with NAFLD were diagnosed with AF, while only $7.9 \%$ of patients without NAFLD had AF. Similarly, an OR of 1.88 (95\% CI, 1.03-3.45) was demonstrated after adjusting for age, sex, study group, diabetes, body mass index, waist circumference, alcohol consumption, smoking, serum alanine aminotransferase concentration, systolic blood pressure, quick index, left ventricular mass index, left atrial diameter, coronary artery disease, atrial natriuretic peptide, and high sensitive C-reactive protein (hsCRP).

A 12 year follow-up of aspartate aminotransferase (AST) and alanine aminotransferase (ALT) levels in 9,333 men and women found a U-shaped association between AF risk and AST/ALT in participating in the Atherosclerosis Risk in Communities Study [14]. The association weakened after adjusting for potential confounders. 3,744 participants without clinical heart failure showed that AST and ALT levels were significantly associated with an increased risk of incidental AF (ALT hazard ratio 1.19,
95\% CI 1.07-1.32, $p=0.002$; AST hazard ratio $1.12,95 \%$ CI 1.01-1.24, $p=0.03$ ) in the Framingham Heart Study Original and Offspring cohorts. The associations remained after excluding moderate-to-severe alcohol consumption [15]. Because circulating levels of liver enzymes, like AST, ALT and gamma glutamyl transpeptidase (GGT), are often important markers of NAFLD. The above two studies suggest that NAFLD could be a predictor of AF [16].

Therefore, regardless of whether patients have type-2 diabetes or hypertension, NAFLD remains a significant independent risk factor of AF, particularly in patients with type-2 diabetes (Table 1). Structural and electrical remodeling of atrium induced by inflammation, insulin resistance, lipid metabolism disorder, and fibrosis may play an important role in NAFLD patients, but unfortunately, underlying mechanisms of linking AF with NAFLD is unclear [17].

\section{The mechanism linking AF with NAFLD}

Although the above-mentioned epidemiologic investigations revealed that NAFLD is closely related to the incidence of AF, there is still a lack of direct evidence of a correlation between NAFLD and AF pathogenesis. Potential mechanisms involve insulin resistance, oxidative stress, and inflammation

\section{The role of adiponectin in the pathogenesis of NAFLD and $\mathbf{A F}$}

Adiponectin is an adipokine secreted by adipocytes that is inversely correlated with body fat. Adiponectin significantly impacts the cellular metabolism of glucose and fatty acids, and has several other properties including anti-inflammation, anti-oxidation, anti-atherosclerosis functions and improving insulin resistance (IR) $[18,19]$. Parasecretion of adiponectin is associated with hypertension, atherosclerosis, NAFLD, AF, cancer, and other diseases [20]. Inflammatory cells infiltrating adipose tissue secrete cytokines, such as tumor necrosis factor- $\alpha$ (TNF- $\alpha$ ), interleukin-6 (IL-6), IL-8, IL-18, and monocyte chemotactic protein-1 (MCP-1), to regulate glucose metabolism, lipid metabolism, and inflammatory response with adiponectin in insulin-sensitive tissues. The imbalance between adipokines and cytokines contributes to the development of IR and NAFLD [21-23]. Furthermore, Hui et al. reported that high TNF- $\alpha$ levels and hypoadiponectinemia are IR-independent features of NASH [24] (Figure 1).

Adiponectin exerts its effects in the liver via AdipoR2, a highly liver-specific adiponectin receptor expressed on the surface of hepatic cells [25]. According to a meta-analysis of serum adiponectin from patients with NAFLD, which analyzed 27 studies with a total of 2,243 participants (including 698 controls and 1,545 patients), a higher serum adiponectin concentration was observed in controls compared to patients with NAFLD and NASH. Furthermore, the serum adiponectin concentration was 
Table 1: The relevance of NAFLD and AF in epidemiology

\begin{tabular}{|c|c|c|c|}
\hline Subjects & Study protocol & Odds ratio/Hazard ratio & Reference \\
\hline $\begin{array}{l}\text { Type } 2 \text { diabetes } \\
\text { patients, } n=400\end{array}$ & Cohort study, follow-up 10 years & $\begin{array}{l}4.49[95 \% \text { CI } 1.6-12.9] \\
\text { adjusted-OR* 6.38 } \\
{[95 \% \text { CI } 1.7-24.2]}\end{array}$ & Giovanni Targher ${ }^{12}$ \\
\hline $\begin{array}{l}\text { Type } 2 \text { diabetes } \\
\text { patients, } n=702\end{array}$ & Cross-sectional study & $\begin{array}{l}3.04[95 \% \text { CI } 1.54-6.02] \\
\text { adjusted-OR 5.88** } \\
{[95 \% \text { CI } 2.72-12.7]}\end{array}$ & Giovanni Targher ${ }^{13}$ \\
\hline $\begin{array}{l}\text { Middle-aged } \\
\text { hypertensive } \\
\text { patients, } n=958\end{array}$ & $\begin{array}{l}\text { Cohort study, mean follow-up } \\
16.3 \text { years (median } 17.6 \text { years, } \\
\text { range } 0-19 \text { years) }\end{array}$ & $\begin{array}{l}\text { Hazard ratio } 1.96(95 \% \mathrm{CI}) \\
1.29-2.97 \\
\text { Adjusted OR*** } 1.88 \\
{[95 \% \text { CI } 1.03-3.45]}\end{array}$ & Aki J. Käräjämäki ${ }^{10}$ \\
\hline
\end{tabular}

*Adjustments for age, sex, hypertension and electrocardiographic features (left ventricular hypertrophy and PR interval).

**Adjustments for age, sex, systolic BP (blood pressure), HbA1c, (glycated haemoglobin), estimated GFR (glomerular filtration rate), total cholesterol, electrocardiographic LVH (left ventricular hypertrophy), COPD (chronic obstructive pulmonary disease), and prior history of HF (heart failure), VHD (valvular heart disease) or hyperthyroidism.

***age, sex, study group, diabetes, body mass index (BMI), waist circumference, alcohol consumption, smoking, serum alanine aminotransferase concentration (ALT), systolic blood pressure, quick index, left ventricular mass index, left atrial diameter, coronary artery disease (CAD), atrial natriuretic peptide (ANP) and high sensitive C-reactive protein (hs-CRP).

higher in patients with NAFLD compared with patients with NASH [26]. The reported differences were observed across the body mass index, age, and sex, and in addition to type-2 diabetes mellitus. Interestingly, in the studies where liver biopsies had been performed in controls, there was no significant difference between controls and patients. Another systematic review included four studies, which involved in
187 histologically confirmed NASH adult patients, revealed that Thiazolidinediones treatment increases circulating adiponectin levels as well as histological improvement in NASH patients [27]. Alisol A 24-acetate was also found to improve NASH likely through adiponectin [28]. Hong et al. found that regular supplementation of soybean embryos might prevent NAFLD through adiponectin-

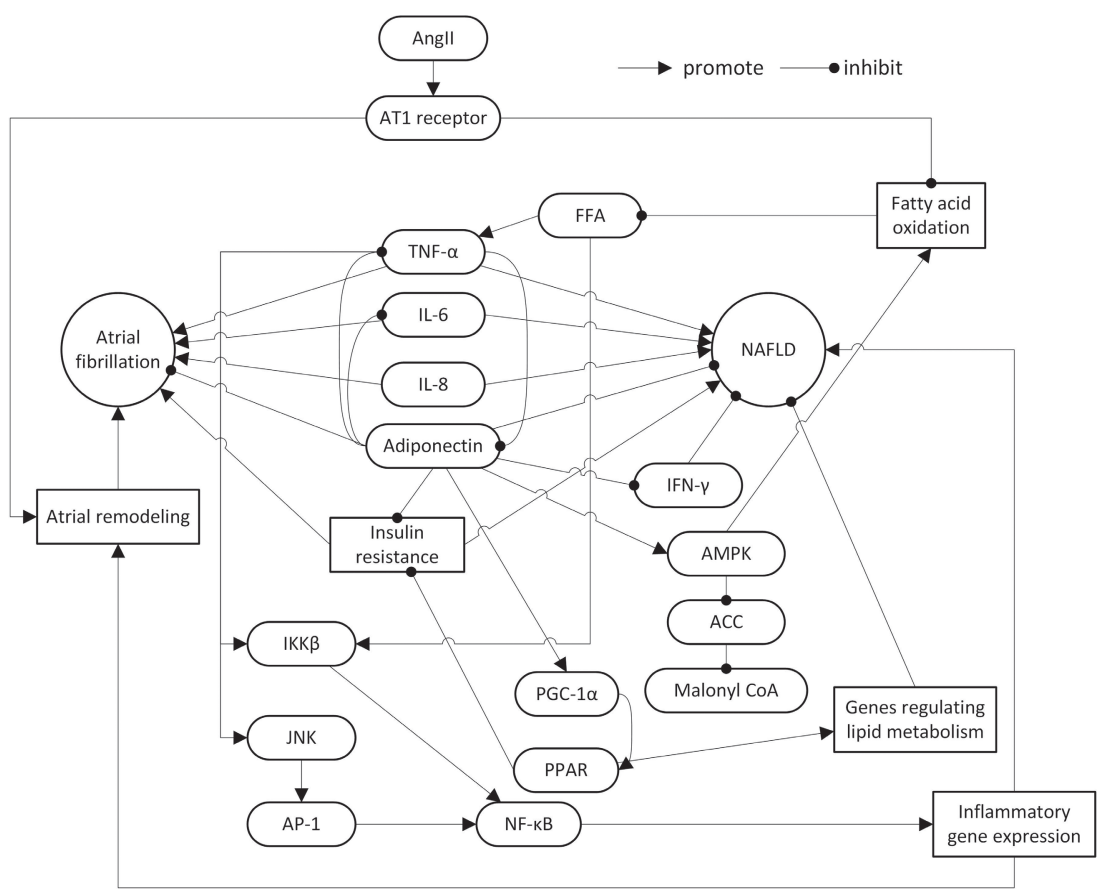

Figure 1: The roles of adiponectin, inflammatory cytokines, AngII and insulin resistance in the pathogenesis of NAFLD and AF. NAFLD: non-alcoholic fatty liver disease; AngII: angiotensin II; AT1: angiotensin II type 1; TNF- $\alpha$ : tumor necrosis factor- $\alpha$; IL: interleukin; IFN- $\gamma$ : interferon- $\gamma$; FFA: free fat acid; AMPK: adenosine monophosphate-activated protein kinase; ACC: acetyl-CoA carboxylase; IKK: inhibitor of nuclear factor kappa-B kinase; JNK: c-Jun N-terminal kinase; AP-1: Activator Protein-1; PPAR: peroxisome proliferator-activated receptor; PGC-1: PPAR $\gamma$ coactivator-1; NF-kB: nuclear factor $\kappa$-light-chain-enhancer of activated B cells. 
mediated AMPK $\alpha$ pathway [29]. Therefore, adiponectin is regarded as an important role for improvement of NAFLD.

Recent studies also reported a correlation between adiponectin and AF. Inflammation and oxidative stress cause atrial remodeling with increasing serum TNF- $\alpha$ level, which is positively correlated with the dilation of the left atrium $[30,31]$. Adiponectin's anti-inflammatory and anti-oxidative properties could potentially improve atrial remodeling. Therefore, the serum adiponectin level may be an indicator for evaluating atrial remodeling in patients with AF [32]. Using eicosapentenoic acid in a rabbit model reduced the incidence of AF by increasing adiponectin concentration and decreasing TNF- $\alpha$ concentration in the atrium tissue and the surrounding adipose tissue [33]. After assessing 90 post-operation patients who underwent cardiac surgery, Kourliouros et al. found that post-operation AF is independent of serum IL-6, serum adiponectin, and epicardial IL-6, but is associated with a significant reduction of epicardial adiponectin [34]. Therefore, epicardial adiponectin has a potential protective effect against post-operation AF. Another study in postoperative coronary artery bypass patients showed that hypoadiponectinemia leads to an increased incidence of obesity, metabolic syndrome, and post-operation AF [35]. Notably, Thiazolidinediones showed a significant reduction of AF in type 2 diabetes, but it is unclear if adiponectin is involved $[36,37]$. However, some studies found higher adiponectin levels might be associated with a greater risk for $\mathrm{AF}$ in older adults [38-40].

The reduction of adiponectin level is a potential common mechanism of NAFLD and AF. However, the correlation between adiponectin and AF, contradicts adiponectin's inhibition of NAFLD and AF genesis and development. Additional work is necessary to define the role of adiponectin in AF.

\section{The role of insulin resistance in the pathogenesis of NAFLD and AF}

Insulin resistance (IR) is the low response of tissue cells (i.e. muscle, adipose tissue, and liver) to circulating insulin. IR primarily results from inefficient insulin uptake and use, and compensatory hyperinsulinemia [41, 42].

IR promotes NAFLD by accelerating NAFLD development and transforming NAFL into NASH [43-45]. Approximately $70 \%$ of patients with type- 2 diabetes suffer from NAFLD [46, 47]. Liver fat is closely correlated with the ability of insulin to suppress lipolysis. In patients with IR, lipase activity is enhanced and increases long-chain fatty acids (LCFA) in portal blood, which results in more LCFA for hepatic cells, thus worsening NAFLD [48]. In fact, in "Obese/Metabolic NAFLD", NAFLD is closely associated with IR. However NAFLD caused by genetic variants, like patatin-like phospholipase domain-containing 3 I148M gene variant, are not associated with IR [49].

IR is also a risk factor for AF pathogenesis [50]. IR enhances pro-inflammatory responses in myocardium cells via IL-1, CRP, and reactive oxygen species (ROS). This results in myocardium remodeling, atrium enlargement, and autonomic neuropathy, and may thus promote the occurrence of AF [51-54]. Bissinger and colleagues reported that diabetes mellitus led to autonomic neuropathy and increased the duration and dispersion of $\mathrm{P}$ wave $[51,55]$. Wang et al. also found that P-wave dispersion and maximum duration are independently associated with IR in patients with metabolic syndrome [56], suggesting that IR contributes to AF development. However, analysis of 3,023 middle-aged to elderly participants from the Framingham Heart Study found that IR does not correlated with incident AF (hazard ratio 1.18, 95\% CI 0.84-1.65, $p=0.34$ ) [57].

It is worth noting that the mechanisms of IR acting on NAFLD and AF are not the same. While increased LCFA plays a crucial role in NAFLD, it is the IR-induced enhancement of inflammation in myocardium and autonomic neuropathy that may be the major cause of AF.

\section{The role of renin angiotensin aldosterone system in the pathogenesis of NAFLD and AF}

Early studies of the renin angiotensin aldosterone system (RAAS) mostly focused on its role in hypertension. However, recently, the role of RAAS in other diseases has attracted great attention. In addition to its regulatory effect on blood pressure, RAAS promotes the organization of fibrosis in some tissues. Angiotensin II (AngII), an important component of RAAS and a pro-inflammatory factor, upregulates cytokines, promotes cell proliferation, and regulates extracellular matrix metabolism via the AngII type I (AT1) receptor [58]. In humans, the AT1 receptor is mainly distributed in blood vessels, the heart, the liver, the brain, the lung, the kidney, and the adrenal cortex; thus, it may be involved in the genesis and development of NAFLD and AF.

RAAS is an important lipid metabolism signaling pathway in the liver of patients with NAFLD. In rodent models, the blockade of RAAS attenuates obesity caused by high fat diets $[59,60]$. Furthermore, knockout rodent models lacking RAAS-related genes such as renin, angiotensin converting enzyme, or bearing liver-specific deletion of AT1 receptor show improved hepatic steatosis [59, 61, 62]. Angiotensin converting enzyme inhibitor and angiotensin receptor blocker have preventive and therapeutic effects against triacylglycerol (TAG) accumulation in the liver [63-67]. This may be associated with the role of AngII in accentuating TAG accumulation in the liver. Its mechanisms involve altering serum free fatty acid and TAG, reducing fatty acid oxidation, regulating secretion of very low density lipoprotein (VLDL), and increasing fatty regeneration. Moreover, AngII suppresses insulin functions by increasing oxidative stress, thus resulting in an increased level of circulating free fatty acid $[60,68,69]$. The activation of RAAS down-regulates the expression of genes related to fatty acid oxidation to suppress the oxidation metabolism of fatty acid $[59,61,70]$. In addition, some cytokines (TNF- $\alpha$, MCP-1, and IL-6) and IR participate in the process of RAAS-related aggravation of NAFLD. 
Angiotensin-converting enzyme inhibitors (ACEi) and AngII receptor blocker (ARB) reduce the risk of developing AF according to retrospective studies from large randomized controlled trials. These findings suggests that the RAAS contributes to the incidence of AF. However, two other trials concluded that upstream RAAS inhibition couldn't increase benefit for AF prevention [71]. Activation of RAAS is an important cause of myocardial fibrosis, and AngII plays a key role in the signaling pathway [72-74]. Myocardial fibrosis causes both electrical and mechanical remodeling of the left atrium, resulting in a higher risk of AF [75-78].

\section{Effects of drugs on NAFLD and AF}

To date, there are no specific drugs that treat both NAFLD and AF. However, several treatments have been reported to exert therapeutic actions on both NAFLD and AF. Among these, statins and RAAS blockers are the most frequently prescribed.

\section{Role of statin in the treatment of NAFLD and AF}

Statins are cholesterol-lowering drugs that are mainly used to treat atherosclerosis. In recent years, the potential therapeutic effect of statins in NAFLD and AF has been postulated.

Considering the high cardiovascular risk in most patients with NAFLD, the use of statins became a reasonable choice in these cases. Despite previous concerns, recent evidence has confirmed the safety of statins and their effects on reducing alanine aminotransferase levels in the liver and the risk of cardiovascular diseases [79, 80]. Indeed, three large randomized controlled studies found that atorvastatin, pravastatin, and pitavastatin could decrease the level of alanine aminotransferase in patients with NAFLD [81-83]. Based on these results, the use of statins to treat patients with NAFLD has been accepted by the standard guidelines $[2,84]$.

Statins improve NAFLD via multiple pathways. Animal studies have shown that statins prevent the development of inflammation and fibrosis in the liver. Their mechanisms include attenuating the activity of stressactivated c-Jun N-terminal kinase (c-JNK), decreasing the expression of transforming growth factor- $\beta$ (TGF- $\beta$ ) and connective tissue growth factor, improving peroxisomal $\beta$-oxidation, inhibiting the activation of hepatic stellate cells, and up-regulating endothelial nitric oxide synthase and induced nitric oxide synthase [85-87]. These effects are mediated by anti-inflammation, anti-apoptosis, and antioxidation. However, due to the lack of histologic evidence, the absence of pathogenesis, and small sample size in currently available studies, the reported results have been inconsistent. Some studies showed that statin treatment reduced hepatic steatosis in the liver [88-91], while other studies did not $[92,93]$. Moreover, improved inflammation was only reported in some of these studies [89-91].
Statins help reduce the incidence of post-operation AF in patients after cardiac surgery [94-97]. A similar effect can be found in patients with end-stage renal disease [98]. A study in Asian patients with AF who were treated with amiodarone showed that atorvastatin significantly reduced the incidence of AF relapse and the level of serum hsCRP [99]. However, another study with patients over 70 years of age undergoing coronary artery bypass grafting showed that statin treatment did not reduce the incidence of AF and mortality [100]. Furthermore, Zheng et al. [80] found that, in 1,922 elective patients after cardiac surgery, the administration of $20 \mathrm{mg}$ rosuvastatin did not attenuate the incidence of AF and cardiac injury, but likely increased the risk of acute kidney injury [101].

However, these results have the risks of discrepancy and bias because they are based on retrospective or observational studies. Therefore, more prospective randomized controlled studies are needed to clarify the role of statin in preventing AF. The mechanism of statins in AF prevention remains vague, but may relate to inflammation and oxidative stress. Serum levels of hsCRP, IL-6, and TNF- $\alpha$ increase significantly in AF and can be decreased by statin [97, 99, 102, 103]. Zakkar et al. [83] also found that oxidative stress and inflammation are important factors in post-operative AF in patients following cardiac surgery [104]. In addition, statins increase the serum level of adiponectin, which is another probable reason for decreasing the incidence of AF and NAFLD [105, 106].

\section{Role of RAAS blockers in the treatment of NAFLD and $\mathbf{A F}$}

RAAS plays a crucial role in the pathogenesis of NAFLD and AF. Previous studies found that using angiotensin receptor blockers or decreasing the level of AngII can increase adiponectin. Therefore, RAAS blockers may be a potential therapeutic for treating NAFLD and AF $[63,66,67]$.

Furthermore, RAAS blockers use other mechanisms for treating NAFLD and AF. For example, losartan was found to suppress the development of liver fibrosis in rats by inhibiting the expression of the Toll-like receptor (TLR4) and nuclear factor 'kappa-light-chain-enhancer' of activated B-cells (NF- $\mathrm{B})$, as well as attenuating lipopolysaccharideinduced increase in myeloid differentiation factor 88 , $\mathrm{NF}-\kappa \mathrm{B}$, and TGF- $\beta$ [107]. In rats with type- 2 diabetes, Qiang et al. demonstrated that valsartan could block the pathological course of liver fibrosis by down-regulating the expression of $\alpha$-smooth muscle actin, TGF- $\beta 1$, TNF- $\alpha$, and MCP-1, and anti-apoptosis to restore the injured hepatic mitochondrial respiratory function [108]. Namisaki et al. also reported losartan as a potential drug for treating NASH due to its ability to suppress liver fibrosis in rats [109]. Furthermore, telmisartan was reported to prevent hepatocarcinogenesis, probably by inhibiting angiogenesis in cirrhosis [110]. 
In patients with chronic heart failure and animal models of AF, RAAS blockers attenuated atrial fibrosis and decreased the incidence of AF $[111,112]$. Angiotensin converting enzyme inhibitors, like enalapril or cilazapril, reduce the duration of $\mathrm{AF}$ in canines with heart failure or pacing-induction via attenuating atrial fibrosis [113-116].

\section{CONCLUSIONS}

NAFLD and AF are common chronic non-infectious diseases with rising incidences. NAFLD is an independent risk factor for AF. The pathogenesis includes decreased adiponectin levels, IR, activation of RAAS, and other common pathways like inflammation, oxidative stress, and fibrosis (Figure 1). While adiponectin can improve NAFLD, higher adiponectin concentrations may correlate with a greater incidence of AF. Adiponectin level does not have a linear relationship with the incidence of AF, a U-shape relationship.

IR is another important factor in the pathogenesis of NAFLD and AF. NAFLD is closely associated with IR in "Obese/Metabolic NAFLD" patients but not in genetic variants NAFLD patients. Moreover, IR increases the occurrence of AF involved in myocardial structural and electrical remodeling, and autonomic neuropathy.

In addition, RAAS contributes to the pathogenesis of NAFLD and AF significantly. The AT1 receptor may play a key role in the signal pathway. Nevertheless, statins and RAAS blockers have the capacity to improve both NAFLD and AF. More research is needed to identify common therapeutic targets for AF and NAFLD.

\section{ACKNOWLEDGMENTS AND FUNDING} article.

There was no financial support or funding for this

\section{CONFLICTS OF INTEREST}

All authors: no conflicts.

\section{REFERENCES}

1. Vernon G, Baranova A, Younossi ZM. Systematic review: the epidemiology and natural history of non-alcoholic fatty liver disease and non-alcoholic steatohepatitis in adults. Aliment Pharmacol Ther. 2011; 34:274-85. https://doi. org/10.1111/j.1365-2036.2011.04724.x.

2. Chalasani N, Younossi Z, Lavine JE, Diehl AM, Brunt EM, Cusi K, Charlton M, Sanyal AJ. The diagnosis and management of non-alcoholic fatty liver disease: practice Guideline by the American Association for the Study of Liver Diseases, American College of Gastroenterology, and the American Gastroenterological Association. Hepatology. 2012; 55:2005-23. https://doi.org/10.1002/hep.25762.
3. Neuman MG, Cohen LB, Nanau RM. Biomarkers in nonalcoholic fatty liver disease. Can J Gastroenterol Hepatol. 2014; 28:607-18.

4. Chacko KR, Reinus J. Extrahepatic Complications of Nonalcoholic Fatty Liver Disease. Clin Liver Dis. 2016; 20:387-401. https://doi.org/10.1016/j.cld.2015.10.004.

5. Marcuccilli M, Chonchol M. NAFLD and Chronic Kidney Disease. Int J Mol Sci. 2016; 17:562. https://doi. org/10.3390/ijms 17040562 .

6. Pistoia F, Sacco S, Tiseo C, Degan D, Ornello R, Carolei A. The Epidemiology of Atrial Fibrillation and Stroke. Cardiol Clin. 2016; 34:255-68. https://doi.org/10.1016/j. ccl.2015.12.002.

7. Chugh SS, Havmoeller R, Narayanan K, Singh D, Rienstra M, Benjamin EJ, Gillum RF, Kim YH, McAnulty JH Jr, Zheng ZJ, Forouzanfar MH, Naghavi M, Mensah GA, et al. Worldwide epidemiology of atrial fibrillation: a Global Burden of Disease 2010 Study. Circulation. 2014; 129:837-47. https://doi.org/10.1161/ CIRCULATIONAHA.113.005119.

8. Miyasaka Y, Barnes ME, Gersh BJ, Cha SS, Bailey KR, Abhayaratna WP, Seward JB, Tsang TS. Secular trends in incidence of atrial fibrillation in Olmsted County, Minnesota, 1980 to 2000, and implications on the projections for future prevalence. Circulation. 2006; 114:119-25. https://doi. org/10.1161/CIRCULATIONAHA.105.595140.

9. Ballestri S, Lonardo A, Bonapace S, Byrne CD, Loria P, Targher G. Risk of cardiovascular, cardiac and arrhythmic complications in patients with non-alcoholic fatty liver disease. World J Gastroenterol. 2014; 20:1724-45. https:// doi.org/10.3748/wjg.v20.i7.1724.

10. Karajamaki AJ, Patsi OP, Savolainen M, Kesaniemi YA, Huikuri H, Ukkola O. Non-Alcoholic Fatty Liver Disease as a Predictor of Atrial Fibrillation in Middle-Aged Population (OPERA Study). PLoS One. 2015; 10:e0142937. https://doi. org/10.1371/journal.pone.0142937.

11. Ozveren O, Izgi C, Eroglu E, Simsek MA, Turer A, Kucukdurmaz Z, Cinar V, Degertekin M. Doppler Tissue Evaluation of Atrial Conduction Properties in Patients With Non-alcoholic Fatty-liver Disease. Ultrason Imaging. 2016; 38:225-35. https://doi.org/10.1177/0161734615595015.

12. Targher G, Valbusa F, Bonapace S, Bertolini L, Zenari L, Rodella S, Zoppini G, Mantovani W, Barbieri E, Byrne CD. Non-alcoholic fatty liver disease is associated with an increased incidence of atrial fibrillation in patients with type 2 diabetes. PLoS One. 2013; 8:e57183. https://doi. org/10.1371/journal.pone.0057183.

13. Targher G, Mantovani A, Pichiri I, Rigolon R, Dauriz M, Zoppini G, Morani G, Vassanelli C, Bonora E. Nonalcoholic fatty liver disease is associated with an increased prevalence of atrial fibrillation in hospitalized patients with type 2 diabetes. Clin Sci (Lond). 2013; 125:301-9. https:// doi.org/10.1042/CS20130036.

14. Alonso A, Misialek JR, Amiin MA, Hoogeveen RC, Chen LY, Agarwal SK, Loehr LR, Soliman EZ, Selvin E. 
Circulating levels of liver enzymes and incidence of atrial fibrillation: the Atherosclerosis Risk in Communities cohort. Heart. 2014; 100:1511-6. https://doi.org/10.1136/ heartjnl-2014-305756.

15. Sinner MF, Wang N, Fox CS, Fontes JD, Rienstra M, Magnani JW, Vasan RS, Calderwood AH, Pencina M, Sullivan LM, Ellinor PT, Benjamin EJ. Relation of circulating liver transaminase concentrations to risk of newonset atrial fibrillation. Am J Cardiol. 2013; 111:219-24. https://doi.org/10.1016/j.amjcard.2012.09.021.

16. Minhas AM, Usman MS, Khan MS, Fatima K, Mangi MA, Illovsky MA. Link Between Non-Alcoholic Fatty Liver Disease and Atrial Fibrillation: A Systematic Review and Meta-Analysis. Cureus. 2017; 9:e1142. https://doi. org/10.7759/cureus. 1142 .

17. Mantovani A, Ballestri S, Lonardo A, Targher G. Cardiovascular Disease and Myocardial Abnormalities in Nonalcoholic Fatty Liver Disease. Dig Dis Sci. 2016; 61:1246-67. https://doi.org/10.1007/s10620-016-4040-6.

18. Combs TP, Marliss EB. Adiponectin signaling in the liver. Rev Endocr Metab Disord. 2014; 15:137-47. https://doi. org/10.1007/s11154-013-9280-6.

19. Wang ZV, Scherer PE. Adiponectin, cardiovascular function, and hypertension. Hypertension. 2008; 51:8-14. https://doi. org/10.1161/HYPERTENSIONAHA.107.099424.

20. Polyzos SA, Kountouras J, Zavos C, Tsiaousi E. The role of adiponectin in the pathogenesis and treatment of non-alcoholic fatty liver disease. Diabetes Obes Metab. 2010; 12:365-83. https://doi.org/10.1111/j.14631326.2009.01176.x.

21. Jarrar MH, Baranova A, Collantes R, Ranard B, Stepanova M, Bennett C, Fang Y, Elariny H, Goodman Z, Chandhoke V, Younossi ZM. Adipokines and cytokines in non-alcoholic fatty liver disease. Aliment Pharmacol Ther. 2008; 27: 412-21. https://doi.org/10.1111/j.1365-2036.2007.03586.x.

22. Tilg H, Hotamisligil GS. Nonalcoholic fatty liver disease: Cytokine-adipokine interplay and regulation of insulin resistance. Gastroenterology. 2006; 131:934-45. https://doi. org/10.1053/j.gastro.2006.05.054.

23. Wong VW, Hui AY, Tsang SW, Chan JL, Tse AM, Chan KF, So WY, Cheng AY, Ng WF, Wong GL, Sung JJ, Chan HL. Metabolic and adipokine profile of Chinese patients with nonalcoholic fatty liver disease. Clin Gastroenterol Hepatol. 2006; 4:1154-61. https://doi.org/10.1016/j.cgh.2006.06.011.

24. Hui JM, Hodge A, Farrell GC, Kench JG, Kriketos A, George J. Beyond insulin resistance in NASH: TNF-alpha or adiponectin? Hepatology. 2004; 40:46-54. https://doi. org/10.1002/hep.20280.

25. Yamauchi T, Kamon J, Ito Y, Tsuchida A, Yokomizo T, Kita S, Sugiyama T, Miyagishi M, Hara K, Tsunoda M, Murakami K, Ohteki T, Uchida S, et al. Cloning of adiponectin receptors that mediate antidiabetic metabolic effects. Nature. 2003; 423:762-9. https://doi.org/10.1038/nature01705.

26. Polyzos SA, Toulis KA, Goulis DG, Zavos C, Kountouras J. Serum total adiponectin in nonalcoholic fatty liver disease: a systematic review and meta-analysis. Metabolism. 2011; 60:313-26. https://doi.org/10.1016/j.metabol.2010.09.003.

27. Polyzos SA, Mantzoros CS. Adiponectin as a target for the treatment of nonalcoholic steatohepatitis with thiazolidinediones: A systematic review. Metabolism. 2016; 65:1297-306. https://doi.org/10.1016/j.metabol.2016.05.013.

28. Zeng L, Tang W, Yin J, Feng L, Li Y, Yao X, Zhou B. Alisol A 24-Acetate Prevents Hepatic Steatosis and Metabolic Disorders in HepG2 Cells. Cell Physiol Biochem. 2016; 40:453-64. https://doi.org/10.1159/000452560.

29. Hong J, Kim S, Kim HS. Hepatoprotective Effects of Soybean Embryo by Enhancing Adiponectin-Mediated AMP-Activated Protein Kinase alpha Pathway in HighFat and High-Cholesterol Diet-Induced Nonalcoholic Fatty Liver Disease. J Med Food. 2016; 19:549-59. https://doi. org/10.1089/jmf.2015.3604.

30. Fu H, Li G, Liu C, Li J, Wang X, Cheng L, Liu T. Probucol prevents atrial remodeling by inhibiting oxidative stress and TNF-alpha/NF-kappaB/TGF-beta signal transduction pathway in alloxan-induced diabetic rabbits. J Cardiovasc Electrophysiol. 2015; 26:211-22. https://doi.org/10.1111/ jce. 12540 .

31. Ziolo MT, Mohler PJ. Defining the role of oxidative stress in atrial fibrillation and diabetes. J Cardiovasc Electrophysiol. 2015; 26:223-5. https://doi.org/10.1111/jce.12560.

32. Shimano M, Shibata R, Tsuji Y, Kamiya H, Uchikawa T, Harata S, Muto M, Ouchi N, Inden Y, Murohara T. Circulating adiponectin levels in patients with atrial fibrillation. Circ J. 2008; 72:1120-4.

33. Kitamura K, Shibata R, Tsuji Y, Shimano M, Inden Y, Murohara T. Eicosapentaenoic acid prevents atrial fibrillation associated with heart failure in a rabbit model. Am J Physiol Heart Circ Physiol. 2011; 300:H1814-21. https://doi.org/10.1152/ajpheart.00771.2010.

34. Kourliouros A, Karastergiou K, Nowell J, Gukop P, Tavakkoli Hosseini M, Valencia O, Mohamed Ali V, Jahangiri M. Protective effect of epicardial adiponectin on atrial fibrillation following cardiac surgery. Eur J Cardiothorac Surg. 2011; 39:228-32. https://doi. org/10.1016/j.ejcts.2010.05.006.

35. Assar O. Low adiponectin level may contribute to higher incidence of postcardiac surgery atrial fibrillation in obese patients. Ann Thorac Surg. 2012; 93:1762-3; author reply 3. https://doi.org/10.1016/j.athoracsur.2011.09.025.

36. Liu T, Li G. Thiazolidinediones as novel upstream therapy for atrial fibrillation in diabetic patients: a review of current evidence. Int J Cardiol. 2012; 156:215-6. https://doi. org/10.1016/j.ijcard.2012.01.058.

37. Liu B, Wang J, Wang G. Beneficial effects of pioglitazone on retardation of persistent atrial fibrillation progression in diabetes mellitus patients. Int Heart J. 2014; 55:499-505.

38. Kizer JR, Benkeser D, Arnold AM, Mukamal KJ, Ix JH, Zieman SJ, Siscovick DS, Tracy RP, Mantzoros CS, Defilippi CR, Newman AB, Djousse L. Associations of total and high-molecular-weight adiponectin with all-cause and 
cardiovascular mortality in older persons: the Cardiovascular Health Study. Circulation. 2012; 126:2951-61. https://doi. org/10.1161/CIRCULATIONAHA.112.135202.

39. Kizer JR, Benkeser D, Arnold AM, Djousse L, Zieman SJ, Mukamal KJ, Tracy RP, Mantzoros CS, Siscovick DS, Gottdiener JS, Ix JH. Total and high-molecular-weight adiponectin and risk of coronary heart disease and ischemic stroke in older adults. J Clin Endocrinol Metab. 2013; 98:255-63. https://doi.org/10.1210/jc.2012-2103.

40. Macheret F, Bartz TM, Djousse L, Ix JH, Mukamal KJ, Zieman SJ, Siscovick DS, Tracy RP, Heckbert SR, Psaty BM, Kizer JR. Higher circulating adiponectin levels are associated with increased risk of atrial fibrillation in older adults. Heart. 2015; 101:1368-74. https://doi.org/10.1136/ heartjnl-2014-307015.

41. Di Meo S, Iossa S, Venditti P. Skeletal muscle insulin resistance: role of mitochondria and other ROS sources. J Endocrinol. 2017; 233:R15-R42. https://doi.org/10.1530/ JOE-16-0598.

42. Strycharz J, Drzewoski J, Szemraj J, Sliwinska A. Is p53 Involved in Tissue-Specific Insulin Resistance Formation? Oxid Med Cell Longev. 2017; 2017:9270549. https://doi. org/10.1155/2017/9270549.

43. Choudhury J, Sanyal AJ. Insulin resistance and the pathogenesis of nonalcoholic fatty liver disease. Clin Liver Dis. 2004; 8:575-94, ix. https://doi.org/10.1016/j. cld.2004.04.006.

44. Gronbaek H, Thomsen KL, Rungby J, Schmitz O, Vilstrup H. Role of nonalcoholic fatty liver disease in the development of insulin resistance and diabetes. Expert Rev Gastroenterol Hepatol. 2008; 2:705-11. https://doi. org/10.1586/17474124.2.5.705.

45. Polyzos SA, Kountouras J, Zavos C. Nonalcoholic fatty liver disease: the pathogenetic roles of insulin resistance and adipocytokines. Curr Mol Med. 2009; 9:299-314.

46. Leite NC, Salles GF, Araujo AL, Villela-Nogueira CA, Cardoso CR. Prevalence and associated factors of nonalcoholic fatty liver disease in patients with type-2 diabetes mellitus. Liver Int. 2009; 29:113-9. https://doi.org/10.1111/ j.1478-3231.2008.01718.x.

47. Targher G, Bertolini L, Padovani R, Rodella S, Tessari R, Zenari L, Day C, Arcaro G. Prevalence of nonalcoholic fatty liver disease and its association with cardiovascular disease among type 2 diabetic patients. Diabetes Care. 2007; 30:1212-8. https://doi.org/10.2337/dc06-2247.

48. Berk PD, Verna EC. Nonalcoholic Fatty Liver Disease: Lipids and Insulin Resistance. Clin Liver Dis. 2016; 20:245-62. https://doi.org/10.1016/j.cld.2015.10.007.

49. Petaja EM, Yki-Jarvinen H. Definitions of Normal Liver Fat and the Association of Insulin Sensitivity with Acquired and Genetic NAFLD-A Systematic Review. Int J Mol Sci. 2016; 17. https://doi.org/10.3390/ijms17050633.

50. Dublin S, Glazer NL, Smith NL, Psaty BM, Lumley T, Wiggins KL, Page RL, Heckbert SR. Diabetes mellitus, glycemic control, and risk of atrial fibrillation. J Gen Intern
Med. 2010; 25:853-8. https://doi.org/10.1007/s11606-0101340-y.

51. Bissinger A, Grycewicz T, Grabowicz W, Lubinski A. The effect of diabetic autonomic neuropathy on P-wave duration, dispersion and atrial fibrillation. Arch Med Sci. 2011; 7:806-12. https://doi.org/10.5114/aoms.2011.25555.

52. Khavandi K, Khavandi A, Asghar O, Greenstein A, Withers S, Heagerty AM, Malik RA. Diabetic cardiomyopathy--a distinct disease? Best Pract Res Clin Endocrinol Metab. 2009; 23:347-60. https://doi.org/10.1016/j.beem.2008.10.016.

53. Rutter MK, Parise H, Benjamin EJ, Levy D, Larson MG, Meigs JB, Nesto RW, Wilson PW, Vasan RS. Impact of glucose intolerance and insulin resistance on cardiac structure and function: sex-related differences in the Framingham Heart Study. Circulation. 2003; 107:448-54.

54. Tadic M, Ivanovic B, Cuspidi C. What do we currently know about metabolic syndrome and atrial fibrillation? Clin Cardiol. 2013; 36:654-62. https://doi.org/10.1002/ clc. 22163 .

55. Dilaveris PE, Gialafos EJ, Andrikopoulos GK, Richter DJ, Papanikolaou V, Poralis K, Gialafos JE. Clinical and electrocardiographic predictors of recurrent atrial fibrillation. Pacing Clin Electrophysiol. 2000; 23:352-8.

56. Wang W, Zhang F, Xhen J, Chen X, Fu F, Tang M, Chen L. $\mathrm{P}$-wave dispersion and maximum duration are independently associated with insulin resistance in metabolic syndrome. Ann Endocrinol (Paris). 2014; 75:156-61. https://doi. org/10.1016/j.ando.2014.05.004.

57. Fontes JD, Lyass A, Massaro JM, Rienstra M, Dallmeier D, Schnabel RB, Wang TJ, Vasan RS, Lubitz SA, Magnani JW, Levy D, Ellinor PT, Fox CS, et al. Insulin resistance and atrial fibrillation (from the Framingham Heart Study). Am J Cardiol. 2012; 109:87-90. https://doi.org/10.1016/j. amjcard.2011.08.008.

58. Border WA, Noble N. Maximizing hemodynamicindependent effects of angiotensin II antagonists in fibrotic diseases. Semin Nephrol. 2001; 21:563-72.

59. Takahashi N, Li F, Hua K, Deng J, Wang CH, Bowers RR, Bartness TJ, Kim HS, Harp JB. Increased energy expenditure, dietary fat wasting, and resistance to dietinduced obesity in mice lacking renin. Cell Metab. 2007; 6:506-12. https://doi.org/10.1016/j.cmet.2007.10.011.

60. Yvan-Charvet L, Quignard-Boulange A. Role of adipose tissue renin-angiotensin system in metabolic and inflammatory diseases associated with obesity. Kidney Int. 2011; 79:162-8. https://doi.org/10.1038/ki.2010.391.

61. Jayasooriya AP, Mathai ML, Walker LL, Begg DP, Denton DA, Cameron-Smith D, Egan GF, McKinley MJ, Rodger PD, Sinclair AJ, Wark JD, Weisinger HS, Jois M, et al. Mice lacking angiotensin-converting enzyme have increased energy expenditure, with reduced fat mass and improved glucose clearance. Proc Natl Acad Sci USA. 2008; 105:6531-6. https://doi.org/10.1073/pnas.0802690105.

62. Nabeshima Y, Tazuma S, Kanno K, Hyogo H, Chayama K. Deletion of angiotensin II type I receptor reduces hepatic 
steatosis. J Hepatol. 2009; 50:1226-35. https://doi. org/10.1016/j.jhep.2009.01.018.

63. Kudo H, Yata Y, Takahara T, Kawai K, Nakayama Y, Kanayama M, Oya T, Morita S, Sasahara M, Mann DA, Sugiyama T. Telmisartan attenuates progression of steatohepatitis in mice: role of hepatic macrophage infiltration and effects on adipose tissue. Liver Int. 2009; 29:988-96. https://doi.org/10.1111/j.1478-3231.2009.02006.x.

64. Kurita S, Takamura T, Ota T, Matsuzawa-Nagata N, Kita Y, Uno M, Nabemoto S, Ishikura K, Misu H, Ando H, Zen Y, Nakanuma Y, Kaneko S. Olmesartan ameliorates a dietary rat model of non-alcoholic steatohepatitis through its pleiotropic effects. Eur J Pharmacol. 2008; 588:316-24. https://doi.org/10.1016/j.ejphar.2008.04.028.

65. Wei Y, Clark SE, Morris EM, Thyfault JP, Uptergrove GM, Whaley-Connell AT, Ferrario CM, Sowers JR, Ibdah JA. Angiotensin II-induced non-alcoholic fatty liver disease is mediated by oxidative stress in transgenic TG(mRen2)27(Ren2) rats. J Hepatol. 2008; 49:417-28. https://doi.org/10.1016/j.jhep.2008.03.018.

66. Yamamoto E, Dong YF, Kataoka K, Yamashita T, Tokutomi Y, Matsuba S, Ichijo H, Ogawa H, KimMitsuyama S. Olmesartan prevents cardiovascular injury and hepatic steatosis in obesity and diabetes, accompanied by apoptosis signal regulating kinase-1 inhibition. Hypertension. 2008; 52:573-80. https://doi.org/10.1161/ HYPERTENSIONAHA.108.112292.

67. Yokozawa J, Sasaki T, Ohwada K, Sasaki Y, Ito JI, Saito T, Kawata S. Down-regulation of hepatic stearoyl-CoA desaturase 1 expression by angiotensin II receptor blocker in the obese fa/fa Zucker rat: possible role in amelioration of insulin resistance and hepatic steatosis. J Gastroenterol. 2009; 44:583-91. https://doi.org/10.1007/s00535-009-0042-x.

68. Ogihara T, Asano T, Ando K, Chiba Y, Sakoda H, Anai M, Shojima N, Ono H, Onishi Y, Fujishiro M, Katagiri H, Fukushima Y, Kikuchi M, et al. Angiotensin II-induced insulin resistance is associated with enhanced insulin signaling. Hypertension. 2002; 40:872-9.

69. Olivares-Reyes JA, Arellano-Plancarte A, CastilloHernandez JR. Angiotensin II and the development of insulin resistance: implications for diabetes. Mol Cell Endocrinol. 2009; 302:128-39. https://doi.org/10.1016/j. mce.2008.12.011.

70. Rong X, Li Y, Ebihara K, Zhao M, Kusakabe T, Tomita T, Murray M, Nakao K. Irbesartan treatment up-regulates hepatic expression of PPARalpha and its target genes in obese Koletsky $(\mathrm{fa}(\mathrm{k}) / \mathrm{fa}(\mathrm{k}))$ rats: a link to amelioration of hypertriglyceridaemia. Br J Pharmacol. 2010; 160:1796-807. https://doi.org/10.1111/j.1476-5381.2010.00835.x.

71. Roberts JD, Dewland TA, Glidden DV, Hoffmann TJ, Arking DE, Chen LY, Psaty BM, Olgin JE, Alonso A, Heckbert SR, Marcus GM. Impact of genetic variants on the upstream efficacy of renin-angiotensin system inhibitors for the prevention of atrial fibrillation. Am Heart J. 2016; 175:9-17. https://doi.org/10.1016/j.ahj.2016.02.002.
72. Wachtell K, Lehto M, Gerdts E, Olsen MH, Hornestam B, Dahlof B, Ibsen H, Julius S, Kjeldsen SE, Lindholm LH, Nieminen MS, Devereux RB. Angiotensin II receptor blockade reduces new-onset atrial fibrillation and subsequent stroke compared to atenolol: the Losartan Intervention For End Point Reduction in Hypertension (LIFE) study. J Am Coll Cardiol. 2005; 45:712-9. https:// doi.org/10.1016/j.jacc.2004.10.068.

73. Sakamuri SS, Valente AJ, Siddesha JM, Delafontaine P, Siebenlist U, Gardner JD, Bysani C. TRAF3IP2 mediates aldosterone/salt-induced cardiac hypertrophy and fibrosis. Mol Cell Endocrinol. 2016; 429:84-92. https://doi. org/10.1016/j.mce.2016.03.038.

74. Patel BM, Mehta AA. Aldosterone and angiotensin: Role in diabetes and cardiovascular diseases. Eur J Pharmacol. 2012; 697:1-12. https://doi.org/10.1016/j. ejphar.2012.09.034.

75. Burstein B, Nattel S. Atrial fibrosis: mechanisms and clinical relevance in atrial fibrillation. J Am Coll Cardiol. 2008; 51:802-9. https://doi.org/10.1016/j.jacc.2007.09.064.

76. Kato T, Yamashita T, Sekiguchi A, Sagara K, Takamura M, Takata S, Kaneko S, Aizawa T, Fu LT. What are arrhythmogenic substrates in diabetic rat atria? J Cardiovasc Electrophysiol. 2006; 17:890-4. https://doi.org/10.1111/ j.1540-8167.2006.00528.x.

77. Lin CS, Pan CH. Regulatory mechanisms of atrial fibrotic remodeling in atrial fibrillation. Cell Mol Life Sci. 2008; 65:1489-508. https://doi.org/10.1007/s00018-008-7408-8.

78. Roessler K, Sommer B, Merkel A, Rampp S, Gollwitzer S, Hamer HM, Buchfelder M. A Frameless Stereotactic Implantation Technique for Depth Electrodes in Refractory Epilepsy Using Intraoperative Magnetic Resonance Imaging. World Neurosurg. 2016; 94:206-10. https://doi. org/10.1016/j.wneu.2016.06.114.

79. Athyros VG, Tziomalos K, Gossios TD, Griva T, Anagnostis P, Kargiotis K, Pagourelias ED, Theocharidou E, Karagiannis A, Mikhailidis DP, Group GSC. Safety and efficacy of long-term statin treatment for cardiovascular events in patients with coronary heart disease and abnormal liver tests in the Greek Atorvastatin and Coronary Heart Disease Evaluation (GREACE) Study: a post-hoc analysis. Lancet. 2010; 376:1916-22. https://doi.org/10.1016/S01406736(10)61272-X.

80. Tikkanen MJ, Fayyad R, Faergeman O, Olsson AG, Wun CC, Laskey R, Kastelein JJ, Holme I, Pedersen TR, Investigators I. Effect of intensive lipid lowering with atorvastatin on cardiovascular outcomes in coronary heart disease patients with mild-to-moderate baseline elevations in alanine aminotransferase levels. Int J Cardiol. 2013; 168:3846-52. https://doi.org/10.1016/j.ijcard.2013.06.024.

81. Athyros VG, Mikhailidis DP, Didangelos TP, Giouleme OI, Liberopoulos EN, Karagiannis A, Kakafika AI, Tziomalos K, Burroughs AK, Elisaf MS. Effect of multifactorial treatment on non-alcoholic fatty liver disease in metabolic syndrome: a randomised study. Curr Med Res Opin. 2006; 22:873-83. https://doi.org/10.1185/030079906X104696. 
82. Han KH, Rha SW, Kang HJ, Bae JW, Choi BJ, Choi SY, Gwon HC, Bae JH, Hong BK, Choi DH, Han KR. Evaluation of short-term safety and efficacy of HMG-CoA reductase inhibitors in hypercholesterolemic patients with elevated serum alanine transaminase concentrations: PITCH study (PITavastatin versus atorvastatin to evaluate the effect on patients with hypercholesterolemia and mild to moderate hepatic damage). J Clin Lipidol. 2012; 6:340-51. https:// doi.org/10.1016/j.jacl.2012.01.009.

83. Lewis JH, Mortensen ME, Zweig S, Fusco MJ, Medoff JR, Belder R, Pravastatin in Chronic Liver Disease Study I. Efficacy and safety of high-dose pravastatin in hypercholesterolemic patients with well-compensated chronic liver disease: Results of a prospective, randomized, doubleblind, placebo-controlled, multicenter trial. Hepatology. 2007; 46:1453-63. https://doi.org/10.1002/hep.21848.

84. Bays H, Cohen DE, Chalasani N, Harrison SA, The National Lipid Association's Statin Safety Task F. An assessment by the Statin Liver Safety Task Force: 2014 update. J Clin Lipidol. 2014; 8: S47-57. https://doi.org/10.1016/j. jacl.2014.02.011.

85. Okada Y, Yamaguchi K, Nakajima T, Nishikawa T, Jo M, Mitsumoto Y, Kimura H, Nishimura T, Tochiki N, Yasui K, Mitsuyoshi H, Minami M, Kagawa K, et al. Rosuvastatin ameliorates high-fat and high-cholesterol diet-induced nonalcoholic steatohepatitis in rats. Liver Int. 2013; 33:301-11. https://doi.org/10.1111/liv.12033.

86. Van Rooyen DM, Gan LT, Yeh MM, Haigh WG, Larter CZ, Ioannou G, Teoh NC, Farrell GC. Pharmacological cholesterol lowering reverses fibrotic NASH in obese, diabetic mice with metabolic syndrome. J Hepatol. 2013; 59:144-52. https://doi.org/10.1016/j.jhep.2013.02.024.

87. Wang W, Zhao C, Zhou J, Zhen Z, Wang Y, Shen C. Simvastatin ameliorates liver fibrosis via mediating nitric oxide synthase in rats with non-alcoholic steatohepatitisrelated liver fibrosis. PLoS One. 2013; 8:e76538. https:// doi.org/10.1371/journal.pone.0076538.

88. Georgescu EF, Georgescu M. Therapeutic options in nonalcoholic steatohepatitis (NASH). Are all agents alike? Results of a preliminary study. J Gastrointestin Liver Dis. 2007; 16:39-46.

89. Kargiotis $\mathrm{K}$, Katsiki N, Athyros VG, Giouleme O, Patsiaoura K, Katsiki E, Mikhailidis DP, Karagiannis A. Effect of rosuvastatin on non-alcoholic steatohepatitis in patients with metabolic syndrome and hypercholesterolaemia: a preliminary report. Curr Vasc Pharmacol. 2014; 12:505-11.

90. Kimura Y, Hyogo H, Yamagishi S, Takeuchi M, Ishitobi T, Nabeshima Y, Arihiro K, Chayama K. Atorvastatin decreases serum levels of advanced glycation endproducts (AGEs) in nonalcoholic steatohepatitis (NASH) patients with dyslipidemia: clinical usefulness of AGEs as a biomarker for the attenuation of NASH. J Gastroenterol. 2010; 45:750-7. https://doi.org/10.1007/s00535-010-0203-y.

91. Rallidis LS, Drakoulis CK, Parasi AS. Pravastatin in patients with nonalcoholic steatohepatitis: results of a pilot study. Atherosclerosis. 2004; 174:193-6. https://doi. org/10.1016/j.atherosclerosis.2004.01.008.

92. Hyogo H, Ikegami T, Tokushige K, Hashimoto E, Inui K, Matsuzaki Y, Tokumo H, Hino F, Tazuma S. Efficacy of pitavastatin for the treatment of non-alcoholic steatohepatitis with dyslipidemia: An open-label, pilot study. Hepatol Res. 2011; 41:1057-65. https://doi. org/10.1111/j.1872-034X.2011.00849.x.

93. Nakahara T, Hyogo H, Kimura Y, Ishitobi T, Arihiro K, Aikata H, Takahashi S, Chayama K. Efficacy of rosuvastatin for the treatment of non-alcoholic steatohepatitis with dyslipidemia: An open-label, pilot study. Hepatol Res. 2012; 42:1065-72. https://doi.org/10.1111/j.1872034X.2012.01034.x.

94. Kuhn EW, Liakopoulos OJ, Stange S, Deppe AC, Slottosch I, Choi YH, Wahlers T. Preoperative statin therapy in cardiac surgery: a meta-analysis of 90,000 patients. Eur J Cardiothorac Surg. 2014; 45:17-26; discussion https://doi. org/10.1093/ejcts/ezt181.

95. Kuhn EW, Slottosch I, Wahlers T, Liakopoulos OJ. Preoperative statin therapy for patients undergoing cardiac surgery. Cochrane Database Syst Rev. 2015: CD008493. https://doi.org/10.1002/14651858.CD008493.pub3.

96. Pierri MD, Crescenzi G, Zingaro C, D'Alfonso A, Capestro F, Scocco V, Brugia M, Torracca L. Prevention of atrial fibrillation and inflammatory response after on-pump coronary artery bypass using different statin dosages: a randomized, controlled trial. Gen Thorac Cardiovasc Surg. 2016; 64:395402. https://doi.org/10.1007/s11748-016-0647-y.

97. Rezaei Y, Gholami-Fesharaki M, Dehghani MR, Arya A, Haghjoo M, Arjmand N. Statin Antiarrhythmic Effect on Atrial Fibrillation in Statin-Naive Patients Undergoing Cardiac Surgery: A Meta-Analysis of Randomized Controlled Trials. J Cardiovasc Pharmacol Ther. 2016; 21:167-76. https://doi.org/10.1177/1074248415602557.

98. Ho LT, Lin LY, Yang YH, Wu CK, Juang JM, Wang YC, Tsai CT, Lai LP, Hwang JJ, Chiang FT, Lin JL, Chen PC. Statin therapy lowers the risk of new-onset atrial fibrillation in patients with end-stage renal disease. Int J Cardiol. 2015; 201:538-43. https://doi.org/10.1016/j.ijcard.2015.01.040.

99. Wang J, Wang AR, Zhang MJ, Li Y. Effects of Atorvastatin on Serum High-Sensitive C-Reactive Protein and Total Cholesterol Levels in Asian Patients With Atrial Fibrillation. Am J Ther. 2017; 24:e20-e9. https://doi.org/10.1097/ MJT.0000000000000344.

100. Kunt A, Ozcan S, Kucuker A, Odabasi D, Sami Kunt A. Effects of perioperative statin treatment on postoperative atrial fibrillation and cardiac mortality in patients undergoing coronary artery bypass grafting: a propensity score analysis. Med Glas (Zenica). 2015; 12:190-5. https://doi. org/10.17392/796-15.

101. Zheng Z, Jayaram R, Jiang L, Emberson J, Zhao Y, Li Q, Du J, Guarguagli S, Hill M, Chen Z, Collins R, Casadei B. Perioperative Rosuvastatin in Cardiac Surgery. N Engl J Med. 2016; 374:1744-53. https://doi.org/10.1056/ NEJMoa1507750. 
102. Ozaydin M. Atorvastatin for reduction of myocardial dysrhythmia after cardiac surgery study. Future Cardiol. 2007; 3:127-9. https://doi.org/10.2217/14796678.3.2.127.

103. Zhang Y, Wang YT, Shan ZL, Guo HY, Guan Y, Yuan HT. Role of inflammation in the initiation and maintenance of atrial fibrillation and the protective effect of atorvastatin in a goat model of aseptic pericarditis. Mol Med Rep. 2015; 11:2615-23. https://doi.org/10.3892/mmr.2014.3116.

104. Zakkar M, Ascione R, James AF, Angelini GD, Suleiman MS. Inflammation, oxidative stress and postoperative atrial fibrillation in cardiac surgery. Pharmacol Ther. 2015; 154:1320. https://doi.org/10.1016/j.pharmthera.2015.06.009.

105. Arnaboldi L, Corsini A. Could changes in adiponectin drive the effect of statins on the risk of new-onset diabetes? The case of pitavastatin. Atheroscler Suppl. 2015; 16:1-27. https://doi.org/10.1016/S1567-5688(14)70002-9.

106. Li R, Chen LZ, Zhao SP, Huang XS. Inflammation Activation Contributes to Adipokine Imbalance in Patients with Acute Coronary Syndrome. PLoS One. 2016; 11:e0151916. https://doi.org/10.1371/journal.pone.0151916.

107. Shirai Y, Yoshiji H, Noguchi R, Kaji K, Aihara Y, Douhara A, Moriya K, Namisaki T, Kawaratani H, Fukui H. Cross talk between toll-like receptor-4 signaling and angiotensin-II in liver fibrosis development in the rat model of non-alcoholic steatohepatitis. J Gastroenterol Hepatol. 2013; 28:723-30. https://doi.org/10.1111/jgh.12112.

108. Qiang G, Zhang L, Yang X, Xuan Q, Shi L, Zhang H, Chen B, Li X, Zu M, Zhou D, Guo J, Yang H, Du G. Effect of valsartan on the pathological progression of hepatic fibrosis in rats with type 2 diabetes. Eur J Pharmacol. 2012; 685:156-64. https://doi.org/10.1016/j.ejphar.2012.04.028.

109. Namisaki T, Noguchi R, Moriya K, Kitade M, Aihara Y, Douhara A, Nishimura N, Takeda K, Okura Y, Kawaratani H, Takaya H, Seki K, Yoshiji H. Beneficial effects of combined ursodeoxycholic acid and angiotensin-II type 1 receptor blocker on hepatic fibrogenesis in a rat model of nonalcoholic steatohepatitis. J Gastroenterol. 2016; 51: 162-72. https://doi.org/10.1007/s00535-015-1104-x.
110. Tamaki Y, Nakade Y, Yamauchi T, Makino Y, Yokohama S, Okada M, Aso K, Kanamori H, Ohashi T, Sato K, Nakao H, Haneda M, Yoneda M. Angiotensin II type 1 receptor antagonist prevents hepatic carcinoma in rats with nonalcoholic steatohepatitis. J Gastroenterol. 2013; 48: 491-503. https://doi.org/10.1007/s00535-012-0651-7.

111. Ehrlich JR, Hohnloser SH, Nattel S. Role of angiotensin system and effects of its inhibition in atrial fibrillation: clinical and experimental evidence. Eur Heart J. 2006; 27:512-8. https://doi.org/10.1093/eurheartj/ehi668.

112. Lozano HF, Conde CA, Florin T, Lamas GA. Treatment and prevention of atrial fibrillation with non-antiarrhythmic pharmacologic therapy. Heart Rhythm. 2005; 2:1000-7. https://doi.org/10.1016/j.hrthm.2005.05.020.

113. Cardin S, Li D, Thorin-Trescases N, Leung TK, Thorin E, Nattel S. Evolution of the atrial fibrillation substrate in experimental congestive heart failure: angiotensindependent and -independent pathways. Cardiovasc Res. 2003; 60:315-25.

114. Li D, Shinagawa K, Pang L, Leung TK, Cardin S, Wang Z, Nattel S. Effects of angiotensin-converting enzyme inhibition on the development of the atrial fibrillation substrate in dogs with ventricular tachypacing-induced congestive heart failure. Circulation. 2001; 104:2608-14.

115. Li Y, Li W, Yang B, Han W, Dong D, Xue J, Li B, Yang S, Sheng L. Effects of Cilazapril on atrial electrical, structural and functional remodeling in atrial fibrillation dogs. $\mathrm{J}$ Electrocardiol. 2007; 40:100.e1-6. https://doi.org/10.1016/j. jelectrocard.2006.04.001.

116. Sakabe M, Fujiki A, Nishida K, Sugao M, Nagasawa H, Tsuneda T, Mizumaki K, Inoue H. Enalapril prevents perpetuation of atrial fibrillation by suppressing atrial fibrosis and over-expression of connexin43 in a canine model of atrial pacing-induced left ventricular dysfunction. J Cardiovasc Pharmacol. 2004; 43:851-9. 